Conf-950512--249

UCRL-JC-119407

PREPRINT

Test Results of a Combined Distributed Ion Pump/Non-Evaporable Getter Pump Design Developed as a Proposed Alternative Pumping System for the PEP-II Asymmetric B-Factory Collider

F. Holdener, D. Behne, D. Hathaway, K. Kishiyama, M. Mugge, W. Stoeffl, K. Van Bibber, C. Perkins, E. Daly, E. Hoyt, M. Nordby, J. Seeman and D. Wright

This paper was prepared for submittal to the

1995 Particle Accelerator Conference and International Conference on High-Energy Accelerators

Dallas, Texas

May 1-5, 1995

April 24, 1995

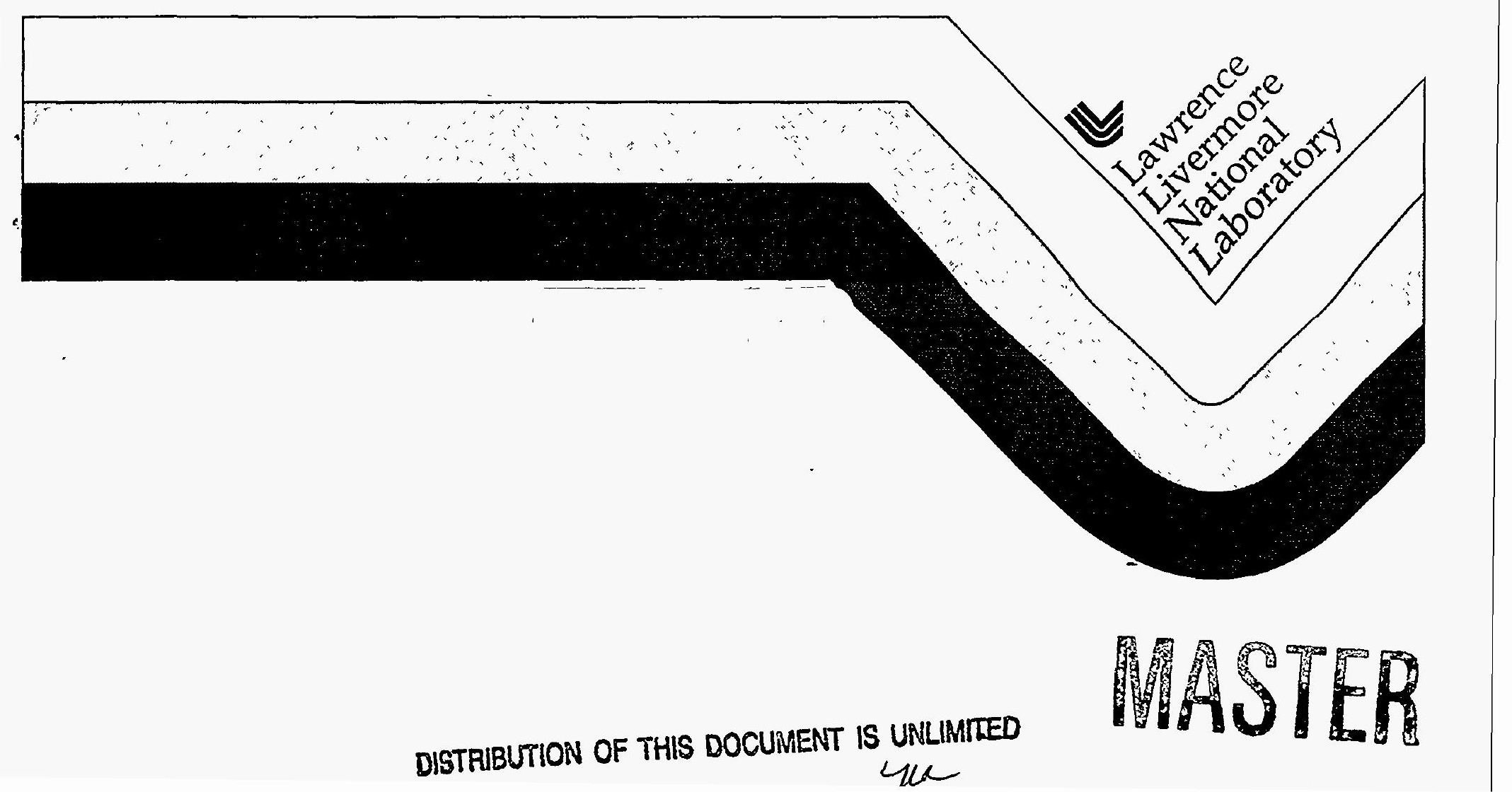




\section{DISCLAIMER}

This report was prepared as an account of work sponsored by an agency of the United States Government. Neither the United States Government nor any agency thereof, nor any of their employees, make any warranty, express or implied, or assumes any legal liability or responsibility for the accuracy, completeness, or usefulness of any information, apparatus, product, or process disclosed, or represents that its use would not infringe privately owned rights. Reference herein to any specific commercial product, process, or service by trade name, trademark, manufacturer, or otherwise does not necessarily constitute or imply its endorsement, recommendation, or favoring by the United States Government or any agency thereof. The views and opinions of authors expressed herein do not necessarily state or reflect those of the United States Government or any agency thereof. 


\section{DISCLAIMER}

Portions of this document may be illegible in electronic image products. Images are produced from the best available original document. 


\title{
Test Results of a Combined Distributed Ion Pump/Non-Evaporable Getter Pump Design Developed as a Proposed Alternative Pumping System for the PEP-II Asymmetric B-Factory Collider*
}

\author{
F. R. Holdener, D. Behne, D. Hathaway, K. Kishiyama, M. Mugge, W. Stoeffl, and K. vanBibber \\ Lawrence Livermore National Laboratory, Livermore, CA 94550
}

\author{
C. Perkins, E. F. Daly, E. Hoyt, M. Hoyt, M. Nordby, J. Seeman, and D. Wright \\ Stanford Linear Accelerator Center, Stanford, CA 94309
}

\begin{abstract}
We have built and tested an all-in-one combination platetype distributed ion pump/non-evaporable getter pump design (DIP/NEG) considered as a proposed alternative pumping system for the PEP-II B-Factory High Energy Ring (HER). The DIP portion of the design used a Penning cell hole size of $12 \mathrm{~mm}$ in a mostly uniform magnetic field of $0.18 \mathrm{~T}$. The NEG portion of the design used commercially available nonevaporable getter material type St-707 $\mathrm{TM}_{[1]}$. A detailed description of the design is presented along with results of pumping speed measurements.
\end{abstract}

\section{INTRODUCTION}

Operation of the PEP-II Asymmetric B-Factory collider in the $9 \mathrm{GeV}, 3 \mathrm{~A}$ mode or $12 \mathrm{GeV}, 1 \mathrm{~A}$ mode places significant pumping speed requirements on the High Energy Ring (HER) vacuum pumping system design. The high gas loads generated by the intense photon synchrotron radiation fan striking the copper vacuum chamber wall necessitate a vacuum pumping scheme that maintains the required HER pressures.

Using a gas desorption coefficient (eta) of $2 \times 10^{-6}$ molecules/photon[1], the calculated gas load at $9 \mathrm{GeV}, 3 \mathrm{~A}$ operation will be $1.06 \times 10^{-6} \mathrm{Torr} 1 / \mathrm{s} / \mathrm{m}$. Average pressures required in the arcs are $10 \mathrm{nTorr}$ at $3 \mathrm{~A}$ operation. The vacuum system of a typical arc cell as seen in Figure 1 consists of two $6 \mathrm{~m}$ long dipole vacuum chambers and two quadrupole chambers $2 \mathrm{~m}$ long each. The quadrupole chambers will be pumped with $60 \mathrm{l} / \mathrm{s}$ noble diode lumped ion pumps (LIPs). The dipole chamber at $6 \mathrm{~m}$ in length precludes pumping from the ends, thus distributed ion pumping is planned to offset the low conductance of the beam tube calculated at $40 \mathrm{l} / \mathrm{s} / \mathrm{m}$.

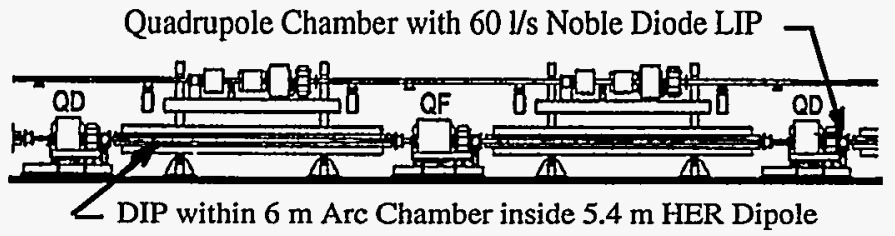

Figure 1. HER arc cell showing DIP location in 5.4 meter dipole

This alternate to distributed ion pumping alone was considered based on the known benefits that non-evaporable getters have in pumping $\mathrm{H}_{2}$ and $\mathrm{CO}$. Concerns about the ability to handle the quantities of gas expected to be generated from the high photon fluxes and uncertainties of the gas desorption properties of the final chamber material, C10100 OF copper, precluded the sole use of non-evaporable gettering as the distributed pumping method in the arc sections of the HER. A distributed pumping speed of $135 \mathrm{l} / \mathrm{s} / \mathrm{m}$ within the beam passage was calculated as adequate to achieve the pressure requirement in the arcs given the latest screen design of calculated conductance of $450 \mathrm{l} / \mathrm{s} / \mathrm{m}$.

\section{PUMPING SYSTEM DESCRIPTION}

To achieve this pumping speed, a combination pumping design, using a plate-type distributed ion pump mounted along side a radiation shielded pair of non-evaporable getter strips was prototyped and tested. The getter material is a patented commercially available product St-707 ${ }^{\mathrm{TM}}[1]$ that consists of $70 \% \mathrm{Zr}-25 \% \mathrm{~V}-5 \% \mathrm{Fe}$ material that is mounted on $30 \mathrm{~mm}$ wide constantan strips. The NEG strips start active pumping after they are heated per manufacturer's recommendation. For this design with side-by-side strips roughly $85 \mathrm{~A}$ at 6 volts/meter was required to reach the recommended $450 \mathrm{C}$ activation temperature. Figure 2 shows a photograph of $1 / 3$ of the combined DIP/NEG prototype. As with the DIP-only design, described in detail in a separate paper presented at this conference[3], a plate-type anode was chosen, as this type is known to have relatively higher pumping speeds than that of the cylindrical type[4] i.e. the basic plate type design has a higher conductance over solid cylinders that allow gas to enter the cells only from the ends. The pump shown is located in a channel space $50 \mathrm{~mm}$ high by $83 \mathrm{~mm}$ wide adjacent to a $6 \mathrm{~mm}$ specially extruded and machined copper screen plate formed to the same shape as the far side of the beam tube. The $6 \mathrm{~mm}$ thick screen considered at the time consisted of a 4 parallel slot screen with $2.5 \mathrm{~mm}$ slots $9 \mathrm{~cm}$ long with $1 \mathrm{~cm}$ spaces.

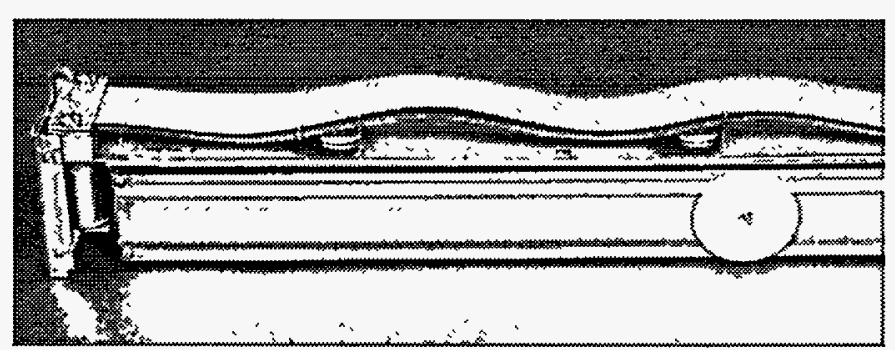

Figure 2. Photograph of DIP/NEG-RG Prototype

* This work was performed under the auspices of the U.S. Department of Energy by Lawrence Livermore National Laboratory and by Stanford Linear Accelerator Center under contracts W-7405-ENG-48(LLNL) and DE-AC03-76SF00515 (SLAC) 
The DIP portion of the 1.1 meter long DIP/NEG design as shown in Figure 3 consists of a laser welded single piece 304 stainless steel anode (316L SS for production version) that has seven equally spaced plates. The seven plates are $0.38 \mathrm{~mm}$ (0.015 in) thick. The anode ends have S-springs $0.38 \mathrm{~mm}$ ( 0.015 in) thick that allow expansion as thermal loads heat it during operation at high pressures as well as during the initial $200 \mathrm{C}$ dipole chamber bakeout. Possible future in-situ 95C bakes within the PEP tunnel will also be accommodated with this spring design. The same spring allows for thermal expansions and contractions during normal operations at low pressures within the PEP tunnel environment. To keep the anode from easily vibrating, it is attached by fasteners at the center to a $3 \mathrm{~mm}$ thick stainless steel NEG radiation shield that also serves as the central support structure for the entire DIP/NEG assembly. The anode holes are $12 \mathrm{~mm}$ in diameter in a closed packed array as seen in Figure 3. The side plates that hold the anode assembly together have been laser welded to the edges in a triangular bridge-type structure for stiffness. The entire sag of the anode was less than $0.025 \mathrm{~mm}$ (0.001 in) when supported only by the ends.

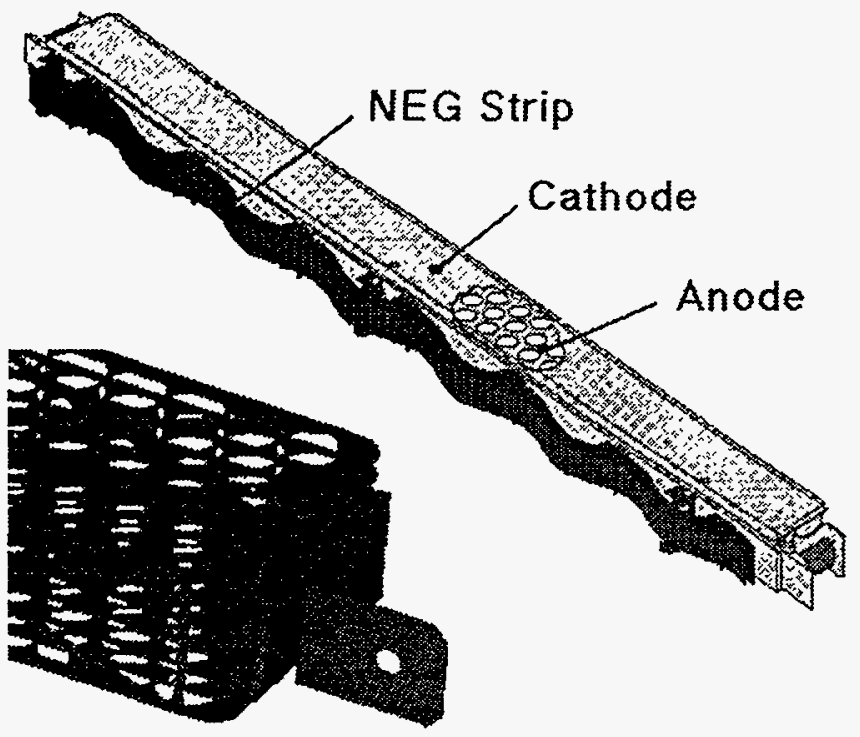

Figure 3. Isometric view of the DIP/NEG Design with a close-up of the Anode End with Thermal Expansion 'S'-spring

The original DIP/NEG design developed used a grounded titanium cathode with a positive hi-voltage anode, i.e. very common type diode-type ion pump. Concern was expressed, based on operation of other electron storage rings, that the DIPs could be injecting ion particles into the beam chamber that are sometimes 'trapped' by the beam causing beam lifetime problems[5]. To avoid this problem, a reversed ground, negative polarity diode ion pump design was used for prototyping and testing. This meant that the anodes are now grounded to the copper chamber and the cathodes are held at a negative high voltage. The new design is labeled a DIP/NEGRG where the RG signifies reverse ground.

For the actual prototype, the module length remained at 1.1 meters because the laser welded anode stiffness allowed this length. This design minimizes the total number of insulators (basically one insulator per module plus one additional at the end of a module string). Fewer insulators help to keep the $\mathrm{I} / \mathrm{P}$, DIP current/pressure value to a minimum which is of benefit when using the ion pump current as a localized method for measuring pressure in the HER. To make the cathode plates stiff enough and to maintain a nominal $4 \mathrm{~mm}$ clearance between all grounded surfaces, the cathodes were partially deformed as seen in Figure 4. The cathode ends were joined and made with fixed supports on the ends with special fastened/welded brackets. We also added two simple posts through the anode, but with adequate clearance at roughly $1 / 3$ meter points along the cathode. The posts, at $6 \mathrm{~mm}(0.25 \mathrm{in})$ in diameter, eliminated three anode cells at these two support locations. On top and bottom of the cathodes, large, specially machined ceramics also proved to be necessary at the two post locations to maintain the cathodes minimum $3 \mathrm{~mm}$ high voltage clearances along its entire length. These ceramics basically made the largest span of any part of a single cathode plate only $1 / 3$ of a meter. The box structure on the end of the cathodes was connected to a simple $19 \mathrm{~mm}$ diameter cylindrical shielded Steatite insulators via "S-springs" of flat $0.38 \mathrm{~mm}(0.015 \mathrm{in}) 304$ stainless steel to allow for thermal expansion along its length in the same way as the grounded anodes.

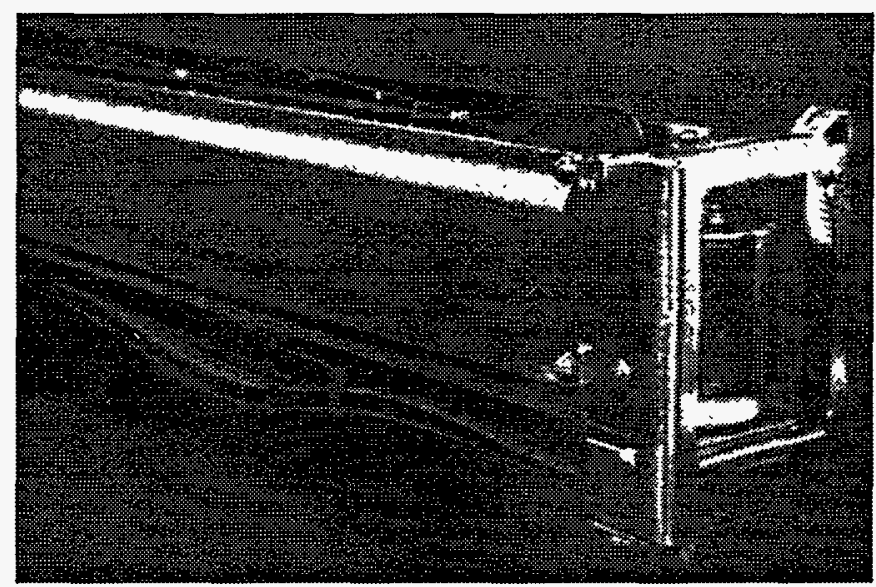

Figure 4. Close-up of DIP/NEG-RG showing Deformed Cathode

The NEG portion of the DIP/NEG-RG is mounted with specially designed electrically insulated stainless steel twopiece clips that snap together at the same time clamping the edges of the NEG strips as seen in Figure 2. Each clip is made to hold the NEG at two locations $25 \mathrm{~mm}$ apart to a set angle to force the parallel NEG strips to expand and contract without touching by approximating a $10 \mathrm{~mm}$ peak-to-peak (P-P) sinewave pattern. In this way, during the large thermal growth only a $2 \mathrm{~mm}$ P-P increase occurs during initial activation and subsequent regenerations to $450 \mathrm{C}$. The NEGs can expand and contract without ever shorting out or touching on any other surfaces. Sliding surfaces as well as overheating is known to generate undesired particulates to be formed from the NEG strips which is minimized with this design.

\section{ANODE AND CATHODE PREPARATION}

The cathodes were baked to $800 \mathrm{C}$ in a turbo pumped evacuated chamber at SLAC to remove the majority of the 
Table 1. Measured Pumping Speeds for NEG-only, DIP-only and DIP/NEG-RG in the actual non uniform

$0.18 \mathrm{~T}$ magnetic dipole field at different constant flows of $\mathrm{N}_{2}$ and $80 \% \mathrm{H}_{2} 20 \% \mathrm{CO}$ gases all with a $600 \mathrm{l} / \mathrm{s} / \mathrm{m} \mathrm{4-Slot} \mathrm{Screen}$

\begin{tabular}{|c|c|c|c|c|c|c|c|c|c|}
\hline \multirow[b]{2}{*}{ Date } & \multirow[b]{2}{*}{ Test Type } & \multicolumn{2}{|c|}{$\mathrm{Q}($ Orif) $\sim 1.0 \mathrm{e}-7 \mathrm{t} \mathrm{t} / \mathrm{s}$} & \multicolumn{2}{|c|}{$\mathrm{Q}$ (Orif) $\sim 5.0 \mathrm{e}-7 \mathrm{t} \mathrm{t} / \mathrm{s}$} & \multicolumn{2}{|c|}{$\mathrm{Q}($ Orif $) \sim 1.0 \mathrm{e}-6 \mathrm{tl} / \mathrm{s}$} & \multicolumn{2}{|c|}{ Q(Orif) $\sim 5.0 \mathrm{e}-6 \mathrm{tl} / \mathrm{s}$} \\
\hline & & \begin{tabular}{|l|} 
Pbar \\
(torr)
\end{tabular} & $\mathrm{S}(1 / \mathrm{sec})$ & \begin{tabular}{l|} 
Pbar \\
(torr)
\end{tabular} & $\mathrm{S}(1 / \mathrm{sec})$ & \begin{tabular}{|l|} 
Pbar \\
(torr)
\end{tabular} & $\mathbf{S}(1 / \mathrm{sec})$ & $\begin{array}{l}\text { Pbar } \\
\text { (torr) }\end{array}$ & $\mathrm{S}(1 / \mathrm{sec})$ \\
\hline $6 / 2 / 94$ & NEG-only N2 & $1.4 \mathrm{E}-08$ & 35 & $2.9 \mathrm{E}-08$ & 37 & 5.4E-08 & 29 & $3.0 \mathrm{E}-07$ & \\
\hline & $5 \mathrm{hr}$ run w/wo turbo & $1.3 \mathrm{E}-08$ & 55 & $3.2 \mathrm{E}-08$ & 33 & $5.6 \mathrm{E}-08$ & 27 & $3.1 \mathrm{E}-07$ & 19 \\
\hline $6 / 3 / 94$ & NEG-Only N2 & & & & & $5.0 \mathrm{E}-08$ & 60 & & \\
\hline & 5 hr run - NEG only & & & & & $1.0 \mathrm{E}-07$ & 20 & & \\
\hline $6 / 9 / 94$ & DIP-only N2 (Almost Dead NEG) & 3.0E-09 & 54 & 8.3E-09 & 76 & $1.7 \mathrm{E}-08$ & 85 & $6.1 \mathrm{E}-08$ & \\
\hline & $5 \mathrm{hr}$ run w/wo turbo & 3.1E-09 & 52 & 8.5E-09 & 77 & $1.7 \mathrm{E}-08$ & 84 & $5.9 \mathrm{E}-08$ & 100 \\
\hline $6 / 10 / 94$ & DIP-only N2 (AImost Dead NEG) & $2.9 \mathrm{E}-09$ & 60 & 7.6E-09 & 79 & $1.2 \mathrm{E}-08$ & 90 & $4.6 \mathrm{E}-08$ & 106 \\
\hline & $5 \mathrm{hr}$ run w/wo turbo & $2.9 \mathrm{E}-09$ & 60 & $7.4 \mathrm{E}-09$ & 83 & $1.2 \mathrm{E}-08$ & 91 & 4.4E-08 & 104 \\
\hline $6 / 14 / 94$ & DIP/NEG Combination N2 & $3.0 \mathrm{E}-09$ & 104 & $9.1 \mathrm{E}-09$ & 112 & $1.6 \mathrm{E}-08$ & 117 & $4.5 \mathrm{E}-08$ & 125 \\
\hline & $5 \mathrm{hr}$ run wo turbo & & & & & & & & \\
\hline $6 / 16 / 94$ & $\begin{array}{l}\text { DIP/NEG Combination(DIP Cond)N2 } \\
5 \mathrm{hr} \text { run wo turbo }\end{array}$ & 2.3E-09 & 66 & 7.3E-09 & 94 & $1.2 \mathrm{E}-08$ & 105 & $3.8 \mathrm{E}-08$ & 120 \\
\hline $6 / 28 / 94$ & DIP/NEG Combination -N2 & $2.5 \mathrm{E}-09$ & 63 & $6.3 \mathrm{E}-09$ & 91 & $1.4 \mathrm{E}-08$ & 99 & 4.7E-08 & 114 \\
\hline & $5 \mathrm{hr} \mathrm{ru}$ & $2.7 \mathrm{E}-09$ & 68 & $6.8 \mathrm{E}-09$ & 84 & $1.5 \mathrm{E}-08$ & 99 & 4.7E-08 & 112 \\
\hline $6 / 28 / 94$ & NEG-Only N2 & $1.2 \mathrm{E}-08$ & 20 & $4.0 \mathrm{E}-08$ & 14 & 7.0E-08 & 20 & $2.8 \mathrm{E}-07$ & \\
\hline $6 / 29 / 94$ & Comb-80\%H $2 / 20 \% \mathrm{CO}$ & $2.9 \mathrm{E}-09$ & 239 & 7.0E-09 & 240 & $1.4 \mathrm{E}-08$ & 258 & 4.1E-08 & 294 \\
\hline & $5 \mathrm{hr} \mathrm{run}$ & 3.2E-09 & 228 & 7.4E-09 & 239 & $1.4 \mathrm{E}-08$ & 263 & 3.3E-08 & 308 \\
\hline & NEG-O & $2.2 \mathrm{E}-08$ & 77 & 4.2E-08 & 54 & 8.3E-08 & 47 & $2.6 \mathrm{E}-07$ & 42 \\
\hline $6 / 30 / 94$ & DIP/NEG Comb-80\%H $2 / 20 \% \mathrm{CO}$ & $2.5 \mathrm{E}-09$ & 396 & 7.2E-09 & 272 & $1.3 \mathrm{E}-08$ & 282 & $4.2 \mathrm{E}-08$ & \\
\hline & $5 \mathrm{hr}$ run & $2.5 \mathrm{E}-09$ & 387 & 7.6E-09 & 278 & $1.3 \mathrm{E}-08$ & 282 & 3.7E-08 & 324 \\
\hline & NEG-Only-8 & $2.2 \mathrm{E}-08$ & 129 & $5.1 \mathrm{E}-08$ & 47 & $9.3 \mathrm{E}-08$ & 41 & $3.3 \mathrm{E}-07$ & 35 \\
\hline $7 / 1 / 94$ & DIP/NEG Comb- $80 \% \mathrm{H} 2 / 20 \% \mathrm{CO}$ & 2.2E-09 & 401 & $6.5 \mathrm{E}-09$ & 273 & $1.1 \mathrm{E}-08$ & 314 & $4.0 \mathrm{E}-08$ & 333 \\
\hline & $5 \mathrm{hr}$ run wo turbo & 2.3E-09 & 369 & $6.6 \mathrm{E}-09$ & 305 & $1.2 \mathrm{E}-08$ & 320 & $3.8 \mathrm{E}-08$ & 363 \\
\hline & NEG-Only- $80 \% \mathrm{H} 2 / 20 \% \mathrm{CO}$ & 2.3E-08 & 213 & $4.8 \mathrm{E}-08$ & 56 & $8.5 \mathrm{E}-08$ & 47 & 3.3E-07 & 41 \\
\hline
\end{tabular}

hydrogen. The Anode assembly was not prebaked for the prototype test, but was baked at the standard $200 \mathrm{C}$ after installation inside of the DIP Test Stand at LLNL[6].

\section{TESTING DESCRIPTION AND RESULTS}

The NEG was activated/regenerated by heating to $450 \mathrm{C}$ for typically a minimum of 1 hour while the system was pumped with a $1000 \mathrm{l} / \mathrm{s}$ turbo in the DIP test chamber at LLNL. The NEG immediately starts pumping upon activation. We quickly learned after doing the first NEG-only pumping speed measurements, that the best NEG activations occurred at lower vacuum pressures. Thus we were able to obtain better pumping speeds after several regenerations, gauge degas operations and system rebakes. In Table 1 is shown the results of several of the pumping speed measurements made. All of the tests for the NEG-only, DIP-only and DIP/NEG-RG combination were performed with $\mathrm{N}_{2}$ and a gas mixture of $80 \% \mathrm{H}_{2} 20 \% \mathrm{CO}$.

\section{RESULTS AND SUMMARY}

The measurements show that the DIP/NEG-RG gave acceptable pumping speeds. The loss of DIP pumping speed by its reduced size was made up by the increased pumping speed of the NEG strips. The requirement to place a solid 3 $\mathrm{mm}$ stainless steel radiation shield between the NEG strips and the beam did however cause a decrease in conductance for the NEGs as was reflected in the measurements. Concern about: (1) the added cost of a more complex design, the NEG material and power supplies for the entire HER, (2) the added requirement of fairly frequent regenerations during initial startup and (3) the added risk of increased particulates from the NEG strips resulted in a decision to use an optimized DIPonly design[3] and not the DIP/NEG-RG design for the actual distributed pumping system for the HER. The knowledge gained from these tests however have shown that the NEG material itself is the best candidate to date for pumping systems being developed for the interaction region (IR)as well as the wiggler sections of the Low Energy Ring (LER).

\section{ACKNOWLEDGMENTS}

The authors wish to thank Mike McDaniel, Vernon Williamson and Pete Tirapelle, the lead designers for the DIP/NEG as well as Eric Ziebarth and his co-workers in the Laser Processes Laboratory, Sheet Metal Fabrication Shops and Cleaning Specialists in Chris Steffani's of MMED. Rudy Carpenter, Al Lopez, Jim Bowman and Philip Keenan all played significant roles in the manufacturing and process step developments.

\section{REFERENCES}

[1] St-707TM manufactured by SAES Getters, Via Gallarate, 215, 20151 Milano, Italy

[2] PEP-II, An Asymmetric B Factory, Conceptual Design Report, June 1993.

[3] Test Results of Pre-Production Prototype Distributed Ion Pump Design for the PEP-II Asymmetric B-Factory Collider, PAC 1995 Particle Accelerator Conference

[4] Y. Suetsugu and M. Nakagawa, Vacuum/Volume 42/1991, Great Britain

[5] Private Comm., Reinhard Brinkmann, DESY, to Mike Zisman, LBL, 11/22/93

[6] Distributed Ion Pump Testing for PEP-II, Asymmetric B-Factory Collider, PAC 1993 Particle Accelerator Conference 